\title{
Density-dependent morphological plasticity and trade-offs among vegetative traits in Eichhornia crassipes (Pontederiaceae)
}

\author{
Eleonora Alvarenga ANDRADE ${ }^{1}$, Mário Eduardo Avelar BARBOSA², Guilherme Ramos DEMETRIO ${ }^{3}$
}

\begin{abstract}
Density-dependent responses are an important component of the organism life-history, and the resource allocation theory is a central concept to the life-history theory. When resource allocation varies due to environmental changes, a plant may change its morphology or physiology to cope with the new conditions, a process known as phenotypic plasticity. Our study aimed to evaluate how plant density affects Eichhornia crassipes allocation patterns. A total of 214 individuals in high and low density were collected. The density effect was observed in all plant traits examined including biomass accumulation. All traits of E. crassipes demonstrated higher values in high density conditions, except for biomass of leaves. Density exhibited a high influence on vegetative traits of $E$. crassipes, but did not influence allocation pattern, since a trade-off among the vegetative traits was not found. The morphological plasticity and the a bsence of trade-offs were discussed as strategies to overcome neighbor plants in competition situations. In high density conditions, there were clear changes in the morphology of the plants which probably allows for their survival in a highly competitive environment.
\end{abstract}

KEYWORDS: Phenotypic plasticity, Plant-environment relationships, Plastic morphology, Macrophyte

\section{Plasticidade morfológica dependente da densidade e compensação entre traços vegetativos em Eichhornia crassipes (Pontederiaceae)}

\begin{abstract}
RESUMO
As respostas dependentes da densidade são um componente importante da história de vida de um organismo e a teoria da alocação de recursos é um conceito central para a teoria da história de vida. Quando a alocação de recursos varia de acordo com mudanças ambientais a planta pode alterar sua morfologia ou fisiologia para lidar com as novas condiçóes, um processo chamado plasticidade fenotípica. Nosso estudo objetivou avaliar como a densidade de plantas afeta os padrôes de alocação de Eichhornia crassipes. Foram coletadas 214 indivíduos em alta e baixa densidade. $\mathrm{O}$ efeito da densidade foi verificado nos traços vegetativos e na biomassa. Todas as características vegetativas medidas em E. crassipes foram maiores em condiçóes de alta densidade com exceção da massa seca de folhas. A densidade apresentou grande influência sobre as características vegetativas de E. crassipes, mas não influenciou os padróes de alocação, já que não foram identificados 'trade-offs' entre as características vegetativas da planta.
\end{abstract}

PALAVRAS-CHAVE: Plasticidade fenotípica, Relaçóes Planta-Ambiente, Morfologia plástica, Macrófita

\footnotetext{
1 Instituto de Educação, Agricultura e Ambiente. Universidade Federal do Amazonas. Rua 29 de agosto, 786 Centro CEP 69800-000, Humaitá-AM. E-mail: eleonoralvarenga@yahoo.com.br

2 Programa de Pós Graduação em Ecologia Aplicada. Universidade Federal de Lavras. CP 3037 CEP 37200-000, Lavras-MG. E-mail: mario.eab@gmail.com

${ }_{3}^{3}$ Programa de Pós Graduação em Ecologia Aplicada. Universidade Federal de Lavras. CP 3037 CEP 37200-000, Lavras-MG. E-mail: gramosdemetrio@gmail.com
} 


\section{INTRODUCTION}

Density-dependent responses are an important component in the life-history of an organism, since this theory seeks to explain how the patterns of growth, maintenance and reproduction of an organism influence its fitness (Stearns 1992). The theory of resource allocation is a central concept in the theory of life history (Stearns 1992), since the allocation of an acquired resource in an organic process makes this resource unavailable to other processes, implying a trade-off (Weiner 2004).

The option of using acquired resources for growth and maintenance processes depends on the balance between the cost of this function and its immediate necessity to the organism (Harper 1977; Weiner 2004). Thus, changes in resource allocation during the ontogeny reflect the organism's priorities throughout its development (Harper and Ogden 1970). Resource allocation may vary according to the plant size or age. Changes in allocation patterns are usually considered as genetically-determined (Weiner 2004), but environmental characteristics can modify the paths of investments of the organism, such as plant density (Madsen 1991; Coelho et al. 2000; Coelho et al. 2005).

When resource allocation varies in response to environmental changes, the plant may modify its morphology or physiology in order to adapt to the new conditions. This process is known as phenotypic plasticity (Schlichting 1986). Aquatic plants, notably, show this adaptive capacity and are better able to respond to their habitat, permitting higher survival rates for the population (Coelho et al. 2005). Therefore, phenotypic plasticity represents a central feature for evolutionary biology, since it has an adaptive nature (Petit et al. 1996). The factors driving the plant phenotypic plasticity may come from biotic or abiotic origins, such as resource availability, sediment heterogeneity and plant density (Xie et al. 2006; Ikegami et al. 2008). Among the biotic factors, plant density is one of the most complex, since its influence can be indirectly mediated by intraspecific competition (Harper 1977; Zou and Wang 2010). Our study aimed to evaluate how the density of plants affects the allocation patterns of the floating herb Eichhornia crassipes (Mart.) Solms.

Aguapé (Eichhornia crassipes (Mart.) Solms, Pontederiaceae) is a floating herb (Souza and Lorenzi 2005). This species is native to the Amazon and is widely distributed among Brazilian wetlands where it spreads as a weed (Souza and Lorenzi 2005; Lorenzi 2008). The E. crassipes is the most studied aquatic plant because of its great ecological importance. It is a habitat for aquatic animals such as young fishes, minnows and insects, and it serves as food for the manatee, an Amazonian species. Moreover, the plant is able to remove heavy metals, nutrients and sediments from the water (Pott and Pott 2000).
In this study we tried to answer the following questions: 1. Is there a difference in allocation patterns between low density plant habitats and high density habitats? 2 . Is there a trade-off between biomass allocation for leaves, and biomass allocation for the root system in E. crassipes? 3. Does plant density cause changes in the trade-off patterns?

\section{MATERIALS AND METHODS}

\section{Study area}

The study was conducted at the Igarapé do Been

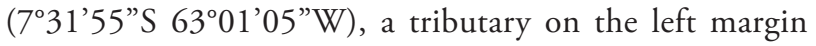
of the Madeira River near Humaitá, Amazonas, in Brazil. The Madeira River is a white-water river which originates in the foothills of the Andes. Andean rocks are of relatively recent geological origins, so modified particles are dissolved and carried to the Amazonian lowlands. Landslides along the river contribute large amounts of sediment to the water (Zeidemann 2001), probably increasing its resource content.

\section{Plant sampling and measurements}

The plants were sampled in May 2011, at the end of the rainy season in this region (Miranda 2002). In this study, the term "individual" is defined as a compact clone of plants possessing one or more ramets. The density of E. crassipes was estimated based on the percentage of water surface covered by the plant, as follows: low densities - less than $50 \%$ of water surface covered by rosettes; high densities - more than $50 \%$ of water surface covered by rosettes (Coelho et al. 2000; Coelho et al. 2005). We collected 107 individuals among both high and low density along the "Igarapé do Been". None of the individuals displayed inflorescences or traces of sexual reproduction.

The plant material was transported to the laboratory in plastic bags where it was processed. The following traits were measured for each individual: maximum plant length, number of leaves, leaf blade length, leaf blade width, maximum root length, maximum petiole length, total plant dry mass, root dry mass, and leaf dry mass. In order to determine biomass, leaves and roots were separated and dried at $60^{\circ} \mathrm{C}$ until it reached constant mass. Leaf biomass was obtained through the aggregate of petiole and leaf blade biomass.

\section{Data analysis}

The effects of density on E. crassipes vegetative traits were tested using student t-tests among all the measured variables (maximum plant length, number of leaves, leaf length, leaf width, maximum root length, maximum petiole length, total plant dry mass, root dry mass, and leaf dry mass) in low and high density conditions.

To assess the existence of trade-offs between biomass allocation for leaves and biomass allocation for the root, linear 
regression analysis was run on biomass data of all the collected individuals. In order to verify if changes in the density condition altered the allocation pattern, the individuals were separated into two groups of high and low density conditions. Linear regression analysis was also conducted for each group.

\section{RESULTS}

High plant density affected most of the measured traits of E. crassipes, except for the dry mass of leaves $(t>2.37, p<0.02$ for all cases) (Table 1). The root exhibited increased length and heavier dry mass in high plant density (Figure 1A e B). The number of leaves was also larger in high plant density (Figure 1C), as well as leaf blade length and width (Figure 1D and E) and petiole length (Figure 1F). High density plants demonstrated both longer petiole and root, resulting in greater total plant length (Figure 1G). No trade-off was found among the vegetative traits when density conditions were analyzed: low density $\left(F=150.033, p<0.001, \mathrm{r}^{2}=0.96\right)$; high density $\left(F=322.360, p<0.001, \mathrm{r}^{2}=0.94\right)$; high and low densities $\left(F=279.575, p<0.001, \mathrm{r}^{2}=0.57\right.$, Figure 2).

\section{DISCUSSION}

The root structure is usually considered a highly plastic trait (Potters et al. 2007; Potters et al. 2009), and root length has been considered an important property to evaluate the degree of plant adjustment to new environmental conditions (Xie et al. 2006). The competition for resources in high density may have influenced the morphology of the root of E. crassipes. There is no enough space for lateral development in higher densities for the plant to obtain sufficient nutrients, so it compensates with root of increased lengths in order to better acquire the resources dispersed in the water as nutrients and oxygen (Coelho et al. 2000). For aquatic macrophytes, an increase in the root length seems to be useful in densely crowded conditions, since longer roots may offer an adaptive advantage for ramets to explore the environment around them (Room 1988; Coelho et al. 2000).

The morphology of leaves is another adaptive trait for aquatic macrophytes (Madsen 1991). In high plant density, space for horizontal growth is restricted, therefore larger petioles and larger leaf surfaces allow an increase in the size of the active photosynthetic area, providing higher exposure to light and enhancing the competitive ability of the ramets (Coelho et al. 2000). For E. crassipes, a larger number of leaves in high plant density was expected (Center and Spencer 1981), but this study is the first to show an increase in leaf blade area within high plant density. For some aquatic plants, such as Salvinia auriculata aublet., an increase in leaf blade and more exposure to light is linked to competitive strategies; higher exposure to light radiation maximizes photosynthesis (Coelho et al. 2000; Coelho et al. 2005). When the plants
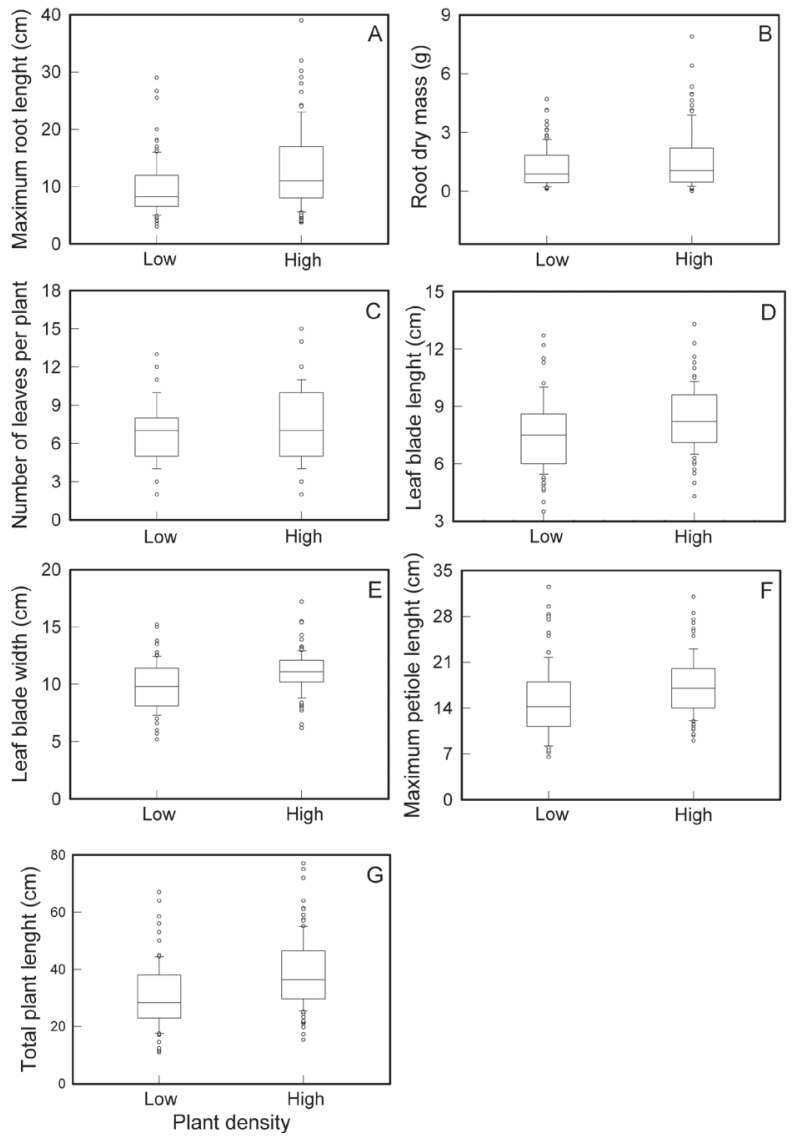

Figure 1 - Box plot of (A) root length, (B) root dry mass, (C) number of leaves, (D) leaf blade length, $(E)$ leaf blade width, $(F)$ petiole length, $(G)$ total plant length in low versus high plant density conditions. The boxes represent the 25th and the 75th percentiles; the lines inside the boxes represent the median; the lines above and under the boxes represent the standard deviations; the circles represents outliers.

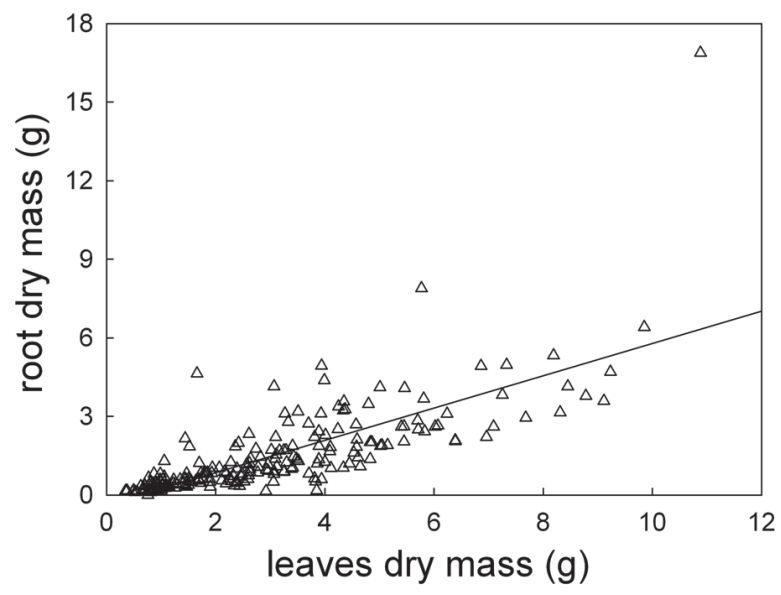

Figure 2 - Relationship between leaf dry mass ( $\mathrm{g}$ ) and root dry mass $(\mathrm{g})$ ( $n=$ 214). The line represents the equation $y=0.6166 x-0.3745$. 
Table 1 - Mean values ( \pm standard deviation) of the measured vegetative traits of $E$. crassipes in high and low densities of plants. The $t$ tests indicate significant differences between all the measured traits with the exception of leaf dry mass at $p=0.05$

\begin{tabular}{llllllllll}
\hline $\begin{array}{l}\text { Plant } \\
\text { density }\end{array}$ & $\begin{array}{l}\text { Maximum plant } \\
\text { length }(\mathrm{cm})\end{array}$ & $\begin{array}{l}\text { Number of } \\
\text { leaves }\end{array}$ & $\begin{array}{l}\text { Leaf length } \\
(\mathrm{cm})\end{array}$ & $\begin{array}{l}\text { Leaf width } \\
(\mathrm{cm})\end{array}$ & $\begin{array}{l}\text { Maximum root } \\
\text { length }(\mathrm{cm})\end{array}$ & $\begin{array}{l}\text { Maximum } \\
\text { petiole length } \\
(\mathrm{cm})\end{array}$ & $\begin{array}{l}\text { Plant total } \\
\text { dry mass }(\mathrm{g})\end{array}$ & $\begin{array}{l}\text { Root dry } \\
\text { mass }(\mathrm{g})\end{array}$ & $\begin{array}{l}\text { Leaf dry } \\
\text { mass }(\mathrm{g})\end{array}$ \\
\hline High & $38.77 \pm 12.22$ & $7.69 \pm 2.92$ & $5.98 \pm 1.59$ & $8.07 \pm 1.73$ & $12.92 \pm 6.93$ & $16.3 \pm 4.48$ & $4.85 \pm 3.98$ & $1.75 \pm 2.13$ & $3.10 \pm 2.10$ \\
Low & $30.53 \pm 10.98$ & $6.90 \pm 2.52$ & $6.05 \pm 1.84$ & $7.85 \pm 1.84$ & $9.92 \pm 4.80$ & $11.45 \pm 5.34$ & $4.08 \pm 2.96$ & $1.19 \pm 1.01$ & $2.88 \pm 2.04$ \\
\hline
\end{tabular}

produce more photosynthates they can invest in processes such as growth and maintenance, enhancing survival rates. In high density plants, leaf blade may be important to increase photosynthesis rates; however, in many cases, the leaves may be subjected to shading conditions by leaves from other plants or even their own. A consensus concerning the real effect of plant density on its size has not yet been established. There is evidence that plant size decreases with plant density (Center and Spencer 1981; Zou and Wang 2010). However, other studies show that plant size increases with plant density (see Coelho et al. 2000; Coelho et al. 2005), suggesting that an increase in plant length in high plant density is a result of superior competitive ability.

In summary, plant density is important to morphology and biomass allocation of E. crassipes, since high density conditions caused clear changes in the morphology of the plants, allowing them to survive in a highly competitive environment. However, the real impact of density in the morphology of aquatic plants is still controversial and more studies are needed to evaluate such patterns. High density conditions may simulate low availability of resources due to competition among individuals, even in nutrient-rich systems such as found in the Madeira River. This reinforces the knowledge that ecological factors lead to plant adaptation and selection.

\section{ACKNOWLEDGMENTS}

The authors are grateful to the NGO Pacto Amazônico for providing logistics and to the students of UFAM / IEAA for the valuable assistance in the field.

\section{REFERENCES}

Center, T.D.; Spencer, N.R. 1981. The phenology and growth of water hyacinth (Eichhornia crassipes (Mart.) Solms) in a eutrophic north-central Florida lake. Aquatic Botany, 10: 1-32.

Coelho, F.F.; Deboni, L.; Lopes, F.S. 2000. Density-dependent morphological plasticity in Salvinia auriculata aublet. Aquatic Botany, 66: 273-280.

Coelho, F.F.; Deboni, L.; Lopes, F.S. 2005. Density-dependent reproductive and vegetative allocation in the aquatic plant Pistia stratiotes (Araceae). Revista de Biologia Tropical, 53: 369-376.
Harper, J.L. 1977. Population Biology of Plants. Academic Press, London. 892p.

Harper, J.; Ogden, J. 1970. The reproductive strategy of higher plants. I. The concept of strategy with special reference to Senecio vulgaris L. Journal of Ecology, 58: 681-698.

Ikegami, M.; Whigham, D.F.; Werger, M.J.A. 2008. Optimal biomass allocation in heterogeneous environments in a clonal plant-spatial division of labor. Ecological Modelling, 213: 156-164.

Lorenzi, H. 2008. Plantas Daninhas do Brasil: terrestres, aquáticas, parasitas e tóxicas 4ed. Instituto Plantarum. Nova Odessa, São Paulo. 672p.

Madsen, J.D. 1991. Resource allocation at the individual plant level. Aquatic Botany, 41: 67-86.

Miranda, E.V. 2002. Padrão de desenvolvimento radial horário do fuste de três espécies florestais típicas da Amazônia utilizando dendômetros automáticos. Thesis, National Institute of Amazonian Research /Amazon University Foundation, Manaus, Amazonas, 75p.

Petit, C.; Thompson, J.D.; Bretagnolle, F. 1996. Phenotypic plasticity in relation to ploidy level and corn production in perennial grass Arrhenatherum elatius. Canadian Journal of Botany, 74: 1964-1973.

Potters, G.; Pasternak, T.P.; Guisez, Y.; Jansen, M.A.K. 2009. Different stresses, similar morphogenic responses: integrating a plethora of pathways. Plant Cell and Environment, 32: 158-169.

Pott, V.J.; Pott, A. 2000. Plantas Aquáticas do Pantanal. Embrapa, Brasília. 404p.

Potters, G.; Pasternak, T.P.; Guisez, Y.; Palme, K.J.; Jansen, M.A. 2007. Stress-induced morphogenic responses: growing out of trouble? Trends in Plant Science, 12: 98-105.

Room, P.M. 1988. Effects of temperature, nutrients and a beetle on branch architecture of the floating weed Salvinia molesta and simulations of biological control. Jornal of Ecology, 76: 826-848.

Schlichting, C.D. 1986. The evolution of phenotypic plasticity in plants. Annual Review of Ecology and Systematics, 17: 667-693.

Souza, V.C.; Lorenzi, H. 2005. Botânica Sistemática: guia ilustrado para identificação das familias de Angiospermas da flora brasileira, baseado em APG II. Instituto Plantarum, Nova Odessa, SP. 640p.

Stearns, S.C. 1992. The Evolution of Life Histories. Oxford University Press, Oxford. 264p.

Weiner, J. 2004. Allocation, plasticity and allometry in plants. Perspectives in Plant Ecology,Evolution and Systematics, 6(4): 207-215. 
Xie, Y.; An, S.; Wu, B.; Wang, W. 2006. Density-dependent root morphology and root distribution in the submerged plant Vallisneria natans. Environmental and Experimental Botany, 57: 195-200.

Zeidemann, V.K. 2001. O Rio das Águas Negras, p.62-87. In: Oliveira, A.A., Daly, D. (Eds.). Florestas do Rio Negro. Companhia das Letras, São Paulo. 344p.

Zou, Y.; Wang, J. 2010. Vegetative and reproductive traits of Sagittaria trifolia (Alismataceae) in response to sediment heterogeneity and plant density. Fundamental and Applied Limnology, 177: 197-208.

Recebido em: 04/07/13

Aceito em: 04/02/2013 
